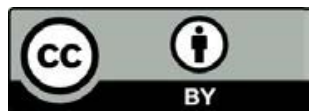

\title{
REMÉDIO AMARGO: ENSAIO DE ANTROPOLOGIA-FILOSÓFICA SOBRE UMA AMBIGUIDADE DA RELIGIÃO
}

Bitter medicine: anthropological and philosophical essay on an ambiguity of religion

\author{
Marcelo Lopes \\ Universidade Federal de Juiz de Fora \\ Doutorando em Ciência da Religião \\ Grupo de Pesquisa - NEPROTES \\ Pesquisador/bolsista de monitoria PPCIR-UFJF \\ e-mail: montanhista-ms@hotmail.com
}

RESUMO: O presente ensaio contempla o viés da religião enquanto remédio. Nesse sentido, privilegia a questão de sua ambiguidade, isto é, seu grande potencial terapêutico e seu alto risco intrínseco de letalidade. Através do instrumental analítico da antropologia-filosófica, procuramos problematizar a temática ora em tela. Mas não nos restringimos a essa disciplina somente. Procuramos uma abordagem mais holística sem, contudo, digredirmos totalmente dessa chave hermenêutica. $\mathrm{O}$ ensaio está dividido em três tópicos, quais sejam: remédio pra quê?, a droga da morte, o fármaco da vida. Procuramos focar naquilo que está colado na preocupação do cotidiano das pessoas, sobretudo a partir do lócus do homo religiosus. A questão de fundo aqui é, portanto, onto-antropológica.

Palavras chave: Homo religiosus, Religião, Remédio, Ambiguidade.

ABSTRACT: This essay considers the bias of religion as remedy. In this regard, emphasizes the question of its ambiguity, that is, its great therapeutic potential and its high inherent risk of lethality. Through the analytical tools of anthropology and philosophy, tried to question the issue now in screen. But we do not restrict ourselves to this discipline only. We seek a more holistic approach without, however, wholly get out wholly this hermeneutical key. The essay is divided into three topics, namely: medicine for what?, the drug of death, the drug of life. We seek to to focus on what's stuck in people's everyday concern, especially since the locus of homo religiosus. The heart of the matter here is, therefore, onto-anthropological.

Keywords: Homo religiosus, Religion, Medicine, Ambiguity. 


\section{Considerações iniciais}

"Eu costumo dizer que a religião é um remédio. Remédio significa duas coisas: tanto aquilo que ajuda a saúde como aquilo que mata. A religião é um remédio nessa ambigüidade” (BATISTA, 1984, p. 115).

Inicialmente, nos parece ser de bom termo esclarecer que o presente ensaio foi pensado durante uma releitura de alguns textos sobre religião do povo, aliás, religiosidade do povo. Porém, não se trata de revisitar essa temática. Ao contrário, pensamos que essa discussão já está, desde muito, bem resolvida nos estudos de religião, quiçá ultrapassada.

Trata-se, portanto, de problematizar a religião como remédio, isto é, como algo de que se precisa, mas que possui, concomitantemente, seu poder terapêutico e seu alto risco intrínseco. Nesse sentido, a frase lapidar de Batista, supracitada aqui como epígrafe, faz parte desses textos e é justamente a ambiguidade da religião, nos termos explicitados na perícope acima, que anima o escopo deste ensaio.

A propósito do título com o qual batizamos este trabalho, é por dever de justiça que referenciamos o texto de José Bittencourt Filho (1996) no qual nos inspiramos, cujo título é o mesmo, ou seja, remédio amargo. Nesse texto, porém, Bittencourt aborda o tema que ele denomina Pentecostalismo Autônomo, hoje mais conhecido como neopentecostalismo. Portanto, o texto de Bittencourt nada tem a ver com nosso enfoque, senão no fato de se estudar o fenômeno religioso e do título propriamente dito.

\section{Pano de fundo: remédio pra quê?}

Em sua brilhante obra sobre antropologia filosófica, O homem quem é ele? Elementos de antropologia filosófica, Batista Mondin assevera que

uma manifestação tipicamente humana é a religião. Ela não está presente nos outros seres vivos, mas somente no homem. E é uma manifestação que, se abarcarmos a humanidade inteira seja com relação ao espaço quanto ao tempo e não somente este ou aquele outro grupo de uma época histórica particular, assume proporções notabilíssimas (MONDIN, 1980, p. 218). 
Assim, parece-nos interessante começar essa reflexão rememorando o papel da religião. Aproveitamos aqui a brilhante assertiva de Rubem Alves sobre o assunto:

\begin{abstract}
Houve tempo em que os descrentes, sem amor a Deus e sem religião, eram raros. Tão raros que eles mesmos se espantavam com sua descrença e a escondiam, como se ela fosse uma peste contagiosa. E de fato era. Tanto assim que não foram poucos os que acabaram queimados na fogueira, para que sua desgraça não contaminasse os inocentes. Todos eram educados para ver e ouvir as coisas do mundo religioso, e a conversa cotidiana, este tênue fio que sustenta visões de mundo, confirmava - por meio de relatos de milagres, aparições, visões, experiências místicas, divinas e demoníacas - que este é um universo encantado e maravilhoso no qual, por detrás e através de cada coisa e cada evento, se esconde e se revela um poder espiritual. (...) $\mathrm{O}$ universo físico se estruturava em torno da alma humana. $\mathrm{E}$ talvez seja esta a marca de todas as religiões, por mais longínquas que estejam umas das outras: o esforço para pensar a realidade toda a partir da exigência de que a vida faça sentido (2002, p. 9).
\end{abstract}

Este relato poético de Alves automaticamente nos remete ao período da Idade Média. Um mundo regido pelo sagrado, no qual o profano, quase sempre, era indesejável, quase espúrio. O cosmos era organizado em termos mágicos, isto é, seres espirituais povoavam o imaginário coletivo, criaturas espirituais benfazejas e os temidos demônios.

Todavia, continua Alves,

alguma coisa ocorreu. Quebrou-se o encanto. O céu, morada de Deus e seus santos, ficou de repente vazio. Virgens não mais apareceram em grutas. Milagres se tornaram cada vez mais raros, e passaram a ocorrer sempre em lugares distantes com pessoas desconhecidas. A ciência e a tecnologia avançaram triunfalmente, construindo um mundo e que Deus não era necessário como hipótese de trabalho. Uma das marcas do saber científico é seu rigoroso ateísmo metodológico: um biólogo não invoca maus espíritos para explicar epidemias; nem um economista, os poderes de inferno para dar contas da inflação, da mesma forma que a astronomia moderna, distante de Kepler, não busca ouvir harmonias musicais divinas nas regularidades matemáticas dos astros (2002, p. 9-10).

$\mathrm{O}$ mundo se desencantou. $\mathrm{Na}$ modernidade, a inexorável marcha da secularização atropelou a religião que, combalida e desalojada da esfera pública, migrou para o mundo do subjetivo, do individual, enfim, um exílio no privado, ao menos no Ocidente. Era de se esperar que a religião, pensada obsoleta em tempos modernos, 
caducasse até a sua inevitável extinção. Aliás, muitos apologetas da modernidade "profetizaram" não só a morte de Deus, mas o fim da religião. Chegara, em fim, a idade da maturidade do Homem. O homo religiosus fora substituído pelo homo sapiens hodiernus.

"Contudo, parece que criar deuses é algo que os seres humanos sempre fizeram. Quando uma idéia religiosa deixa de funcionar, simplesmente a substituem" (ARMSTRONG, 2008, p. 16). Nesse sentido, vale relembrar aqui que aquilo que anima a religião, isto é, o sagrado, possui uma característica que o sociólogo Roger Bastide (2006) formulou de forma magistral, qual seja, sua selvageria. Aí reside seu potencial. O sagrado pode estar domesticado ou docilizado, porém, possui, de forma latente, seu instinto selvagem. Em determinadas circunstâncias, ele pode irromper. Sobre isso Mendonça comenta, fazendo referência a Roger Bastide, que "o homem é uma 'máquina de fazer deuses' que, à medida em que o sagrado se torna 'frio' (froid) nas instituições religiosas (igrejas) recria o sagrado 'quente' (chaud), que ele chama de 'sagrado selvagem"” (MENDONÇA, 2004, p. 31).

No tempo presente, a selvageria do sagrado tem irrompido em diversas religiões, em variados níveis e em muitos lugares do mundo. Observando esse fenômeno, alguns entusiastas da religião "escreveram precoces necrológios do sagrado, e fizeram profecias do desaparecimento da religião e do advento de uma ordem social totalmente secularizada e profana" (ALVES, 2002, p. 50), na qual a religião se tornaria inócua, insipiente e, por isso mesmo, desnecessária. Logo, tenderia a desaparecer.

Pois bem, a secularização ocorreu de fato, e ainda ocorre, mas a religião não se exauriu. Nesse mérito, como bem expôs Danièle Hervieu-Lèger a propósito de algumas utopias pontuais do cientificismo e do positivismo, "a racionalidade está longe de se impor uniformemente em todos os registros da vida social e nós, sob muitos aspectos, somos mais conscientes disso do que nunca. A racionalidade, no entanto, não deixa de representar a referência que mobiliza as sociedades modernas" (2008, p. 31). É, pois, nesse nimbo cultural bastante fluido e polimorfo chamado pós-modernidade que a religião se pereniza. A profecia positivista do fim da religião não se concretizou. Há, inclusive, os mais entusiastas sobre esse ressurgimento e perenização da religião como, por exemplo, Gilles Kepel (1991), que publicou um livro cujo título, bastante 
emblemático, é: A revanche de Deus: cristãos, judeus e muçulmanos na reconquista do mundo.

Entretanto, esse tema da sobrevida da religião na modernidade é deveras polêmico. Com o fito de evidenciar tal celeuma, citaremos duas leituras contrastantes do mesmo fenômeno. Primeiramente um apologista, o já citado Kepel:

observar os movimentos religiosos que então florescem um pouco por toda parte no mundo é nos interrogar por meio deles a respeito das mutações de conjunto que as sociedades contemporâneas conheceram nos últimos 25 anos, mutações cujos efeitos a opinião sente sem dominar as causas. Observar esses movimentos - por mais fantásticos, aberrantes e fanáticos que sejam em certos casos - é levar a sério o discurso que eles oferecem e as formas alternativas de socialização que procuram construir dentro da confusão inspirada por um universo onde não encontram mais as próprias marcas (1991, p. 22).

Por outro lado, Antônio Flávio Pierucci faz uma aguda crítica a tal leitura sobre a religião no tempo presente:

Que não a tenha suprimido ou extirpado, vá lá, nem era o caso; mas... não a expulsou de onde? - pergunto eu. Havê-la banido do centro mesmo que articula arquitetonicamente a coesão do corpo social, pergunto eu, é pouco? Desbancá-la do seu papel de matriz cultural totalizante, insisto, é pouco? Terem abandonado "dossel sagrado" (Berger, 1997), num processo altamente dinâmico e generalizado de especialização institucional, as esferas normativas do direito positivo moderno e da ética racional, as esferas expressivas da arte moderna e do entretenimento e, last but not the least, as esferas cognitivointelectuais da filosofia e da ciência, é pouco? Pois me parece que foi assim, contentando-se com o pouco que sobrou para a religião na moderna civilização ocidental - a saber, a esfera privado-íntima, e olhe lá! - que começou a tomar forma entre os cientistas sociais da religião essa atitude mental de valorização simpatizante do "retorno do sagrado", fenômeno assim nomeado por alguns já na segunda metade dos anos 70 (Bell, 1977; Alves, 1979; Wilson, 1979), posição que no início dos 90 viria a ser rebatizada com este que eu particularmente reputo um título de extremo mau gosto, La revanche de Dieu (Kepel, 1991). Mau gosto, primeiro, por seu injustificado triunfalismo e, em segundo lugar, pela marca acintosamente abraâmico-monoteísta do seu significante central. Do eclipse à reconquista: chrétiens, juifs et musulmans à la reconquête du monde, diz o excludente subtítulo de Kepel (1997, p. 103).

Somente a aposição dessas duas leituras contrastantes já nos fornece subsídios suficientes para perceber que não há consenso acadêmico no tocante ao 
assunto. Em todo caso, as mudanças céleres e abissais que ocorreram em várias partes do mundo, sobretudo nos dois últimos séculos, como a secularização, a laicidade do Estado, o pluralismo religioso e a globalização, por exemplo, propiciaram mudanças profundas, é bem verdade, na forma como o homo religiosus (pós) moderno passou a praticar sua religião ou religiosidade no tempo presente.

Mas o fato é que a religião não se exauriu.

Talvez o projeto inacabado da modernidade tenha justamente na religião o seu maior embate e derrota. Ao contrário, do que foi anunciado, a religião não perdeu a força, a fé cristã não foi banida, a experiência religiosa negou a ideia de que religião é expressão somente da alienação, daí não faltar em muitos contextos da África, da Ásia e da nossa América Latina a relação intrínseca entre religião e revolução, mas mesmo na Europa esta relação existiu e hoje é retomada como forma de superar uma visão exageradamente negativa acerca da religião. A ideia de que a modernidade se implantaria na medida em que a religião se retirasse de cena, não vingou. A modernidade avançou, mas a religião também. A modernidade agoniza, a religião recupera lugares perdidos (MAGALHÃES, 2012, p. 11-12).

Com efeito, parece que há uma premência humana no que toca a uma busca por produção de sentido ou uma necessidade de uma experiência transcendental ou algo que o valha. Talvez seja aí nessa necessidade ontológica que resida a função terapêutica da religião.

\section{A droga da morte}

"De algo sempre haveremos de morrer, mas já se perdeu a conta aos seres humanos mortos das piores maneiras que seres humanos foram capazes de inventar. Uma delas, a mais criminosa, a mais absurda, a que mais ofende a simples razão, é aquela que, desde o princípio dos tempos e das civilizações, tem mandado matar em nome de Deus" (SARAMAGO apud TEIXEIRA, 2002, p. 155).

"Com ou sem religião, pessoas boas farão coisas boas e pessoas más farão coisas más. Porém, para pessoas boas fazerem coisas más, é preciso religião" (WEINBERG apud PEDREIRA, 2014, p. 107). 
As epígrafes supracitadas se referem explicitamente à religião como remédio que mata. Em certo sentido, há que se reconhecer, existe fundamentos históricos bastante sólidos para tais críticas. Entretanto,

tornou-se lugar comum em muitos âmbitos de pesquisa apresentar a religião como responsável por quase todas as desgraças do mundo, incluindo a repressão sexual, a beligerância das culturas e das civilizações, o poder despótico dos governantes e as diferentes formas de intolerância no mundo. Especialmente as religiões chamadas de monoteístas (judaísmo, cristianismo e islamismo) emergem como objetos principais das críticas (MAGALHÃES, 2012, p. 7).

No entanto, nestas poucas laudas não poderíamos abordar todas as mazelas atribuídas à religião. Portanto, privilegiaremos um fenômeno tão antigo quanto à própria religião, mas que está ainda mais em voga atualmente, qual seja: a guerra santa. Com efeito, a guerra santa tem perpassado a história das mais diversas religiões pelo mundo. No entanto, é preciso aclarar essa expressão guerra santa, de modo a melhor compreender o fenômeno ao qual nos referimos. Ocuparemo-nos disso um pouco mais adiante.

Sublinhe-se que já nas sociedades tribais a questão da violência envolvendo a religião não era algo incomum. Por vezes, tribos inteiras se engajavam numa batalha pelo seu deus. A configuração do evento, não raro, prefigurava uma guerra de deuses, no qual o deus de uma tribo guerreava com outro deus através de desafios hierofânicos. Podemos citar o conhecido exemplo bíblico veterotestamentário do profeta Elias contra os profetas de Baal.

O que estava em jogo nessa disputa era, para além da fidelidade dos israelitas a YHWH, o próprio status de divindade dos deuses envolvidos na celeuma: “Se é o Senhor que é Deus, segui-o, e se é Báal segui-o!" (BÍBLIA, 1 Reis 18:21).

O texto bíblico refere-se ao episódio como uma grande vitória do deus de Israel:

Elias aproximou-se de todo o povo e disse: "Até quando dançareis num pé e noutro?" Se é o Senhor que é Deus, segui-o, e se é Báal segui-o! Mas o povo não lhe respondeu uma só palavra. Elias disse ao povo: "sou o único profeta do Senhor que resta, ao passo que os profetas de Báal são quatrocentos e cinquenta. Dêem-nos pois dois 
novilhos; eles escolherão um, fá-lo-ão em pedaços e o porão sobre a lenha, mas sem acender o fogo; e farei o mesmo com o outro novilho; pô-lo-ei sobre a lenha, mas não acenderei o fogo. Depois invocareis o nome de vosso Deus enquanto eu invocarei o nome do Senhor. O deus que responder pelo fogo, é ele o deus". Todo o povo respondeu: "A proposta é boa". Elias disse aos profetas de Báal: "Escolhei vós um novilho e preparai-o, já que sois mais numerosos; invocai o nome do vosso deus, mas não acendais o fogo". Eles tomaram o novilho que ele lhes dera, prepararam-no e depois invocaram o nome de Báal, desde a manhã até o meio-dia, dizendo: "Báal, responde-nos!" Mas não houve nem voz nem quem respondesse. (...) Elias disse a todo o povo: Aproximai-vos de mim!" E todo o povo se aproximou dele. Ele restaurou o altar do Senhor, que tinha sido demolido. (...) Chegada a hora da oferenda, o profeta Elias aproximou-se e disse: "Senhor, Deus de Abraão, de Isaac e de Israel, saibam todos hoje que és o Deus de Israel, que eu sou o teu servo e que foi graças à tua palavra que fiz todas estas coisas. Responde-me, Senhor, responde-me: que este povo conheça que és tu, Senhor, que és Deus; que és tu que reconduzes a ti o coração do teu povo". O fogo do Senhor desceu e devorou o holocausto, a lenha, as pedras, o pó, e absorveu a água que estava no foco. Vendo isso, todo o povo se lançou com a face por terra e disse: "É o Senhor que é Deus; é o Senhor que é Deus!" Elias lhe disse: "Prendei os profetas de Báal! Que nenhum escape!" E prenderam-nos. Elias fê-los descer à torrente do Qishon, onde os degolou (BÍBLIA, 1 Reis 18:21-41. Grifo nosso).

Contudo, conforme se pode perceber, a despeito do evento mítico desse desafio hierofầnico, como resultado da guerra dos deuses, houve uma violência real contra os profetas de Baal. Este último representava a idolatria. O exclusivismo de YHWH não podia tolerar tal comportamento por parte de seus adoradores, e uma lição exemplar tinha de ser aplicada àqueles que ajudaram a desviar o povo de Israel de seu Deus.

Notadamente, o princípio de ação no texto em tela é o da intolerância. Este princípio é a base da guerra santa. Aproveitando aqui o ensejo, por guerra santa entendemos ações violentas que se revestem de uma aura sagrada, e que quase sempre recebem uma fundamentação ou legitimação religiosa. Obviamente, esta definição não esgota o sentido da expressão. Ademais, cada conflito religioso em sua época e local guarda especificidades que reforçarão um ou outro tom desse matiz.

Cientes do anacronismo e do contexto social diferenciado, para fins didáticos, podemos empreender uma comparação da violência ocorrida na narrativa bíblica que citamos logo acima com a violência religiosa que o grupo extremista Estado 
Islâmico (ISIS) perpetra no tempo presente na Síria e no Iraque. Veremos que ambos praticaram violência em nome de sua religião, isto é, degolaram os infiéis.

Do ponto de vista histórico-social, e até mesmo teológico, existem diferenças abissais entre a guerra santa de Elias e a guerra santa do ISIS. Porém, do ponto de vista factual, ambos mataram em nome de seu deus ou de sua religião. Sabe-se que Israel à época do episódio bíblico aqui referenciado era um conglomerado de clãs capitaneados pelo rei Acabe, que além do parentesco, tinham como fator agregador a religião. Assim, a defesa da fé ${ }^{1}$ como fator de preservação da cultura e até mesmo da integridade nacional tornava a guerra santa, em certo sentido, plausível. Ainda que discordemos da violência perpetrada.

Já o ISIS não possui esse senso de integridade nacional. Ao contrário, seus militantes são recrutados dos mais diversos locais do mundo e de nacionalidades distintas. Com efeito, o fator de unidade é a religião. Notamos, portanto, através de exemplos históricos, que de fato a religião pode tornar-se a droga da morte.

Segundo Whittaker,

a religião pode ser o mais explosivo dos identificadores culturais porque envolve valores profundamente arraigados. A ameaça à religião de alguém põe em risco não só o presente, mas também o passado e o futuro culturais. Muitas religiões, inclusive o cristianismo e o islamismo, têm tanta conviç̧ão de que estão certas que não hesitam em empregar a força para conseguir adeptos. O terrorismo em nome da religião pode ser particularmente violento. Como os outros terroristas, os religiosamente motivados emprestam certeza moral a seus atos e mesmo sanção divina. O que, de outra forma, poderia ser considerado ato de desespero, transforma-se em dever religioso na mente do terrorista religiosamente motivado. Isso ajuda a explicar o alto grau de comprometimento e determinação dos que arriscam a morte entre os extremistas dos grupos religiosos (2005, p. 46-47).

A guerra santa no islamismo possui termo específico: Jihad. O que, no entanto, muitos ignoram é que

jihad, na língua árabe, significa a luta entre o bem e o mal, travada para a purificação espiritual - a chamada "guerra santa", imposta aos muçulmanos pelo Alcorão em defesa do Islã (submissão voluntária à

\footnotetext{
${ }^{1} \mathrm{O}$ termo é conhecido no meio teológico como apologética. Porém, a defesa se dá em termos de argumentação "racional", de modo a evitar o falseamento de sua própria doutrina e realizando uma crítica da fé do interlocutor, no fito de desacreditá-la.
} 
vontade de Deus). Doutrinariamente, há quatro modalidades de empreendê-la: resguardando-se dos maus sentimentos; praticando boas ações; propagando por todos os meios a fé islâmica e combatendo os infiéis. Assim foi utilizada para justificar as guerras de expansão do Islamismo, deflagradas a partir do século VI. Atualmente, a conceituação de jihad varia conforme a interpretação que se der ao Alcorão (KEPEL, 2003, p. 5).

Ademais, existe diferença entre jihad maior e jihad menor ${ }^{2}$. Contudo, ocorre que grupos como Boko Haram, Al Qaeda e o próprio ISIS, por exemplo, baseiam-se numa leitura bastante estreita do jihad. Na verdade, encobre-se suras ${ }^{3}$, pretere-se um $\bar{a} y \bar{a} t^{4}$ em detrimento de outro, como por exemplo: "Combatei, pela causa de Deus, aqueles que vos combatem, porém, não pratiqueis agressão, porque Deus não estima os agressores" (ALCORÃO, Sura 2:190). ${ }^{5}$ Essa hermenêutica enviesada e míope do Alcorão tem por objetivo referendar as atrocidades cometidas por terroristas travestidos de religiosos.

No entanto, em termos propriamente religiosos, há que se reconhecer a pretensão universalista e totalitária do Alcorão. Segundo o teólogo islâmico Sami Armed Isbelle, a mensagem corânica, enquanto

mensagem final, através do último mensageiro, ela passou a ser direcionada para toda a humanidade e válida para todos os tempos até o dia do juízo final. Essa religião aborda tudo que é importante na vida do ser humano por meio dos ensinamentos contidos nas suas fontes principais, que são o Alcorão, último livro revelado por Deus para toda a humanidade, e a Sunna, ou seja, os ditos e as práticas do profeta Muhammad (Que abênção e a paz de Deus estajam sobre ele ${ }^{6}$ ). No Islam, não existe uma separação da vida de devoção e da vida diária do homem. O Islam é um sistema de vida completo que possui seus próprios sistemas político, econômico, jurídico e penal, que são, na verdade, os temas desse livro. Desse modo, procuraremos

\footnotetext{
${ }^{2}$ Para um aprofundamento do conceito de jihad, recomendamos ao leitor o texto: ISBELLE, Sami Armed. O Estado Islâmico e sua organização: sistema político, sistema econômico, sistema jurídico, sistema penal, conceito de jihad. Rio de Janeiro: Qualitymark, 2007, sobretudo o intervalo das páginas 49 a 98 , que tratam especificamente do jihad.

${ }^{3}$ Suras divisões do Alcorão num total de 114. São como capítulos da Bíblia.

${ }^{4}$ Āyāt é a subdivisão da sura. Pode ser comparada aos versículos da Bíblia.

${ }^{5} \mathrm{Na}$ verdade, a obra em referência é: NARS, Helmi. Tradução do sentido do Nobre Alcorão para a língua portuguesa, Sura 2:190. Tendo em mente que para os muçulmanos o Alcorão verdadeiro está somente na língua árabe, para facilitar a referenciação, trataremos as citações de Nars como se fosse do próprio Alcorão.

${ }^{6}$ Há uma tradição no Islã que sempre que o nome do profeta Maomé (Muhammad) é mencionado, deveser fazer a seguinte saudação: "Que abênção e a paz de Deus estajam sobre ele". Essa saudação é também abreviada como S.A.A.S ou S.A.W.S, que expressa essa mesma saudação em árabe: șallā llāhu 'alay-hi wa-sallam ou Sallallahu alayhi Wa sallam.
} 
mostrar como se organiza o Estado Islâmico através desses sistemas, já que a religião como um todo só poderá ser posta em prática com a existência de um Estado Islâmico (2007, p. 1, grifo nosso).

Essa cosmovisão descrita acima é uma concepção teológica e, como era de se esperar, nela há um tom apologético na qual se interpenetram religião e política, religião e Estado, religião e judiciário, explicitando dessa forma o desejo de ingerência da religião em todos os âmbitos da vida.

No entanto, tal condicionamento ou intento, foi notado também pelas demais Ciências Humanas. Podemos citar, como um bom exemplo dessa leitura mais científica do fenômeno, a análise feita pelo historiador da terceira geração dos Annales ${ }^{7}$, Marc Ferro:

De fato, durante séculos - da destruição do Templo de Jerusalém até a criação do Estado de Israel -, o judaísmo foi realmente uma religião, e uma religião no sentido ocidental e atual da palavra. Enquanto desde a conversão de Constantino, em 312 d.C., o cristianismo foi associado ao Estado antes de se fundir a ele, tanto que as modalidades da relação entre Igreja e o Estado alimentaram toda a história do Ocidente. O Islã, ao contrário, desde a origem é de uma só vez o Estado, o poder político e o comunitário, fazendo um conjunto com a religião. Esta não é apenas um simples setor da vida, ainda que, segundo as circunstâncias, seus adeptos passem de uma religiosidade inerte, com seus conformismos, a uma fé profunda ou o contrário. De forma que distinções tais como a distinção entre a Igreja e o Estado e aquela que se formula entre a vida privada e a ordem pública não têm o mesmo sentido que no mundo cristão. A dissociação que pode existir no Ocidente entre essas instâncias não implica, em qualquer parte e a qualquer hora, uma solução ideológica do político e do religioso. $\mathrm{O}$ Islã é, de qualquer forma, uma "cultura histórica à qual se agrega o Estado" (2008, p. 16).

Com essa concepção totalizante de mundo, o Islã precisa de uma base sólida que possa nortear precisamente todo o modo de agir nesse mundo sagrado-profano. $\mathrm{O}$ Alcorão é, por excelência, essa base e esse norte. Fala não somente do celeste porvir, mas do cotidiano, sobretudo. O Islã, nesse sentido, talvez, mais que os outros monoteísmos semíticos, leva ao limite o ser uma religião do Livro.

\footnotetext{
${ }^{7}$ Para uma melhor compreensão do termo, ver, por exemplo, o artigo de José Costa D’ Assunção Barros (v. 4 n. 8, jul/dez 2010).
} 
Obviamente não é somente o Islã que possui uma mundivisão totalizante. Basicamente todos os monoteísmos possuem, em maior ou menor grau, essa característica. Utilizamos o Islã como exemplo, pois ele vive este momento histórico. Mas que dizer das Cruzadas e da Santa Inquisição, por exemplo? Do mesmo modo, que poderíamos dizer dos assentamentos israelenses, ilegais, em áreas palestinas? Por seu turno, a Intifada com seus atos violentos gerados pela absoluta inferioridade bélica e pelo desespero, não poderia ser também denominada guerra santa? Portanto, não seria de todo falacioso afirmar que praticamente todas as religiões possuem, em certo grau, um potencial de letalidade.

\section{O fármaco da vida}

A contrario sensu, a religião pode sim, ser um remédio para a humanidade. Nesse sentido, é plausível pensar que quando alguém se dispõe a sujeitar-se a uma prática terapêutica ou a uma indicação medicamentosa, por mais absurdas que essas possam parecer, sejam elas religiosas ou não, no limite, o que esse alguém deseja é a manutenção da vida ou a sua melhora qualitativa. Para o homem, a finitude da vida e a incerteza do post mortem é algo que desde tempos imemoriais inquietam o ser humano. Talvez por isso o homem tenha criado seus símbolos, na expectativa de transcender a inescapável realidade da morte. Segundo a teopoética de Rubem Alves,

símbolos assemelham-se a horizontes. Horizontes: onde se encontram eles? Quanto mais deles nos aproximamos, mais fogem de nós. E, no entanto, cercam-nos atrás, pelos lados, à frente. São o referencial de nosso caminhar. Há sempre os horizontes da noite e os da madrugada... As esperanças do ato pelo qual os homens criaram a cultura, presentes em seu próprio fracasso, são horizontes que nos indicam direções. Essa é a razão por que não podemos entender uma cultura quando nos detemos na contemplação de seus triunfos técnicos/práticos. Porque é justamente no ponto no qual ela fracassou que brota o símbolo, testemunha das coisas ainda ausentes, saudade de coisas que não nasceram... Aqui surge a religião, teia de símbolos, rede de desejos, confissão de espera, horizonte dos horizontes, a mais fantástica e pretensiosa tentativa de transubstanciar a natureza (2002, p. 23-24).

Em sua obra, O suspiro dos oprimidos, Rubem Alves, ao analisar a religião enquanto linguagem do amor se utiliza das postulações filosóficas de Feuerbach acerca 
da religião. Para Feuerbach, "a religião tem a sua base na diferença essencial entre o homem e o bruto - os brutos não tem religião. (...) Mas qual é a diferença essencial entre o homem e o bruto? A resposta mais simples, mais geral e também mais popular a esta questão é - a consciência" (1984, p. 43).

Conforme já indicamos anteriormente, a consciência de sua situação limite, isto é, a finitude da vida e a incerteza do além fermentaram o sentimento religioso da humanidade. Do ponto de vista histórico, "o indício mais antigo de prática relacionada à religião do homem e mulher pré-histórico [sic!], é o sepultamento. Que está intimamente ligada, as fontes mais antigas e numerosas da pré-história, que são as ossadas. A prática da inumação revela uma preocupação com a vida após a morte" (BEZERRA, 2011, p. 2).

Já no âmbito da história propriamente dita, "o homem das sociedades tradicionais é, por assim dizer, um homo religiosus, mas seu comportamento enquadrase no comportamento geral do homem" (ELIADE, 2008, p. 20). De fato, uma das características universais do ser humano é a sua religiosidade, pois não existe sociedade sem algum tipo de religião ou religiosidade, por mais secularizada que possa parecer.

Ademais,

é bem sabido que se o homem não precisasse de "salvação" as religiões seriam inúteis, mas elas têm igualmente se tornado bastante supérfluas em um outro caso: quando não são mais capazes de sanar as doenças e os incômodos físicos e psicológicos cotidianos do homem. É essa segunda questão que hoje mostra-se mais flagrante e de algum modo põe em dificuldade as religiões e especialmente a religião cristã. Contudo, a incapacidade ou a declarada incompetência do cristianismo em "sanar" os males e as doenças dos homens de hoje não pode ser considerado um fato expiado. Trata-se de uma omissão bastante grave, porque o homem contemporâneo é, antes de tudo, um ser doente de corpo e espírito, um paciente e um sofredor que sabe que está doente e que pede, com absoluta prioridade, para ser "curado" (TERRIN, 1998, p. 149).

Aí reside a função terapêutica da religião. Ou seja, enquanto fármaco da vida, da esperança. Aqui não estamos evocando a cura no sentido de taumaturgia ou da alopatia, mas no sentido de proporcionar uma visão de mundo que faça valer a pena o existir. Trata-se, portanto, de produção de horizontes de sentido e construção de cosmovisões religiosas que criem esperança. 
Todavia, não se engane o leitor, pois não fazemos aqui uma apologética da religião. Ao contrário, pensamos que esse fenômeno humano não carece disso. Aliás, enquanto objeto de estudo possui relativa autonomia em nosso ponto de vista. Antes que sejamos julgados por isso, importa, desde já, esclarecer que não se trata de um discurso apologético ou apaixonado.

Pois bem, alguns críticos da religião podem até mesmo ponderar que essa nossa visão é romântica e não condiz com a realidade histórica das mais diversas formas de religião e religiosidades conhecidas. De fato, o contraponto tem relativa pregnância. Mas basta um pouco de honestidade intelectual e boa vontade para com o fenômeno religioso para que alguns sofismas se desfaçam.

Ademais, conforme analisou Willian Paden, "os pontos de observação são freqüentemente fixos, singulares e defensivos" (2001, p. 15). Paden afirma ainda que o pesquisador de determinada escola

fala a partir de um certo lugar, e desse lugar vê o todo da religião nas categorias de seu horizonte limitado. Cada qual vê apenas as características do tema que se encaixam em sua própria perspectiva, enquanto todos os outros aspectos permanecem indistintos, ou obscurecidos, sem interesse e, para todos os propósitos inexistentes (2001, p. 15).

Assim, que poderiam dizer os acusadores da religião de ser somente alienação diante da proposta conscientizadora e mobilizadora da Teologia da Libertação? Do mesmo modo, aqueles que consideram a religião como neurose apenas, que análise poderiam fazer diante da inclusividade e da consideração pelos desejos humanos da Teologia Queer? Isso sem levar em consideração o legado de religiosos como Mahatma Gandhi e Martin Luther King Jr., por exemplo.

Os exemplos religiosos supracitados atestam que a

crítica religiosa à religião faz parte da história das profecias e da intelectualidade (...), contemplando desde os vários movimentos reformistas, heréticos, proféticos, numa lista significativa de nomes, ações, processos, eventos. (...) O presente ensaio dialoga com esta tradição, mas procura resgatar tradições, falas, conselhos e práticas das religiões que se levantam contra o perigo que cada religião guarda em si mesma, justamente por tratar de uma crença em forças absolutas. Os perigos advindos das certezas infindas sempre estiveram no âmbito do exercício critico da própria religião. A 
primeira crítica à religião nasce dentro de si mesma. Só os íntimos sabem o poder embrutecedor e devastador dos cúmplices. A religião conhece, num exercício de autocrítica, os perigos que ela mesma representa (MAGALHÃES, 2012, p. 8-9).

Portanto, um pouco de empatia e honestidade intelectual podem facilmente iluminar outra face do fenômeno religioso por vezes obscurecida e sem interesse, conforme afirmou Willian Paden (2001).

Além disso, é importante salientar a contribuição das religiões e religiosidades num outro sentido, qual seja, a da terapêutica propriamente dita. Segundo o professor da Universidade de Green Bowling, em Ohio (EUA), Kenneth Pargament,

há religiões que contêm muitas ferramentas disponíveis, como rituais que ajudam as pessoas a criar meios para desenvolver mudanças mentais durante crises. São meios de reinterpretar traumas de modo mais significativo, generoso e benevolente, de encontrar significados nas mais difíceis situações, de conter e controlar impulsos. Chamamos essas ferramentas de suporte espiritual. Uma delas é a busca de suporte em deus, que ajuda a manter a pessoa firme durante crises. Outra é o suporte da comunidade religiosa. Há ferramentas, as quais chamamos de "ressignificação religiosa benevolente", que dão sentido ao sofrimento, ao trauma e a doenças, por meio de um contexto superior, generoso e benevolente [a pessoa atribui a crise a um propósito divino]. Podem constatar que é talvez uma oportunidade de se aproximar mais de deus, de amadurecer espiritualmente ou uma chance para conhecer mais sobre si mesmo. Assim, pelo ponto de vista religioso, a dor e o sofrimento não têm a palavra final, eles são parte de algo mais amplo (2015, p. 1).

Assim, parece-nos que a religião pode sim ser entendida como o fármaco da vida. Para tanto, basta que o lócus daquele que observa foque seus atributos essenciais e que cooperam para que o homem seja mais feliz, que contribuem para a fraternidade e o diálogo mútuo e profícuo entre os homens.

\section{Considerações finais}

"A diferença entre um remédio e um veneno está só na dosagem". Paracelso - Médico e físico do séc. XVI.

A modo de conclusão, remetemo-nos ao início deste ensaio, ou seja, à proposta do texto propriamente dita. Nosso intuito aqui foi o de pensar a religião como 
um remédio em sua ambiguidade de ser concomitantemente medicamento e veneno, isto é, remédio que cura e droga que mata. Procuramos apresentar ao leitor um viés dessa temática através do instrumental analítico da antropologia-filosófica, mas não nos restringimos somente a tal disciplina, como o leitor pode observar.

Também não se pretendeu exarar respostas totalizantes ou exaustivas, mas problematizar, quase despretensiosamente, esta ambiguidade da religião. Aqui, finalmente, é preciso falar sobre o adjetivo amargo, pois também qualifica ambiguamente o remédio. Isto é, para alguns, a religião pode funcionar como a cicuta. Acetosa, acerba, e que causa somente o mal. Para outros, no entanto, conquanto amarga, mantém a vida e, por isso mesmo, possui abissal importância.

Por fim, aqui vai uma opinião pessoal. Como estamos tratando com remédio, nos parece ser bastante sóbrio levar em consideração o fator posologia. Sim, posologia grosso modo quer dizer dosagem, e dosagem aponta para equilíbrio. Portanto, seria de bom termo que a religião como um remédio fosse assim: longe dos extremos, perto do diálogo.

\section{Referenciais}

ALVES, Ruben. O que é religião? São Paulo: Loyola, 2002.

O suspiro dos oprimidos. São Paulo: Edições Paulinas, 1984.

ARMSTRONG, Karen. Uma história de Deus: quatro milênios de busca do judaísmo, cristianismo e islamismo. São Paulo: Companhia das Letras, 2008.

BARROS, José Costa D' Assunção. A escola dos Annales: considerações sobre a História do Movimento. Revista História em Reflexão: v. 4, n. 8 - UFGD - Dourados, jul/dez 2010. Disponível em: $<$ http://www.periodicos.ufgd.edu.br/index.php/historiaemreflexao/article /view/953/588>. Acesso em: 25 mai. 2014.

BASTIDE, Roger. O sagrado selvagem e outros ensaios. São Paulo: Companhia das Letras, 2006.

BATISTA, Mauro. Abordagem pastoral da religiosidade do povo. In. QUEIROZ, José J. (Org.). A religiosidade do povo. São Paulo: Paulinas, 1984. p. 109-122.

BEZERRA, Karina. História geral das religiões. Observartório Transdisciplinar das Religiões no Recife. Recife, set. 2011. Disponível em: 
$<$ http://www.unicap.br/observatorio2/wp-content/uploads/2011/10/HISTORIAGERAL-DAS-RELIGIOES-karina-Bezerra.pdf $>$. Acesso em: 18 nov. 2015.

BÍBLIA - Tradução Ecumênica. Tradução: L.J. Baraúna. et al. São Paulo: Loyola, 1994. $2480 \mathrm{p}$.

BITTENCOURT FILHO, José. Remédio amargo. In: ANTONIAZZI, Alberto et al. Nem anjos nem demônios: interpretações sociológicas do pentecostalismo. Rio de Janeiro: CERIS; Petrópolis: Vozes, 1996. p. 24-33.

ELIADE, Mircea. O sagrado e o Profano: a essência das religiões. São Paulo: Martins Fontes, 2008. $191 \mathrm{p}$.

FERRO, Marc. O choque do Islã: séculos XVIII-XXI. Rio de Janeiro: Biblioteca do Exército, 2008.

HERVIEU-LÉGER, Danièle. O peregrino e o convertido: a religião em movimento. Petrópolis: Vozes, 2008.

ISBELLE, Sami Armed. O Estado Islâmico e sua organização: sistema político, sistema econômico, sistema jurídico, sistema penal, conceito de jihad. Rio de Janeiro: Qualitymark, 2007. 224 p.

KEPEL, Gilles. Jihad: expansão e declínio do islamismo. Rio de Janeiro: Biblioteca do Exército, 2003.

. A revanche de Deus: cristãos, judeus e muçulmanos na reconquista do mundo. São Paulo: Siciliano, 1991.

MAGALHÃES, Antonio Carlos de Melo. Religião: crítica e criatividade. São Paulo: Fonte Editorial, 2012.

MENDONÇA, Antonio Gouvêa. A experiência religiosa e a institucionalização da religião. Estudos Avançados, São Paulo, v. 18, n.52, set.-dez. 2004. p. 29-46. Disponível em: <http://dx.doi.org/10.1590/S0103-40142004000300004>. Acesso em: 27 ago. 2013.

MONDIN, Batista. O homem. Quem é ele? Elementos de antropologia filosófica. São Paulo: Paulus, 1980.

NARS, Helmi. TRADUÇÃO do sentido do Nobre Alcorão para a língua portuguesa. Medina: Complexo de impressão do Rei Fahd, [entre 1982 e 1992]. 1065 p.

PADEN, William E. Interpretando o sagrado. São Paulo: Paulinas, 2001.

PARGAMENT, Kenneth. Na guerra ou na depressão: professor lista estratégias espirituais para enfrentar crises. Entrevista concedida à Secretaria de Comunicação UFJF. Disponível em: <http://www.ufff.br/secom/2015/11/12/na-guerra-ou-na- 
depressao-professor-lista-estrategias-espirituais-para-enfrentar-crises/>. Acesso em: 13 nov. 2015.

PEDREIRA, Daniel Santana. O ateísmo e os ateus. São Paulo: Edição do Autor, 2014.

PIERUCCI, Antônio Flávio. Reencantamento e dessecularização: a propósito do autoengano em sociologia da religião. Novos Estudos CEBRAP, São Paulo, n. 49, p. 99-118, set./nov. 1997.

TEIXEIRA, Faustino L. C. Diálogo inter-religioso: o desafio da acolhida da diferença. Perspectiva Teológica, Belo Horizonte, n. 34, p. 155-177, 2002. Disponível em: $<$ http://www.faje.edu.br/periodicos2/index.php/perspectiva/article/view/630/1053>.

Acesso em: 11 dez. 2015.

TERRIN, Aldo Natale. O Sagrado Off Limits: a experiência religiosa e suas expressões. São Paulo: Loyola, 1998.

WHITTAKER, David J. Terrorismo: um retrato. Rio de Janeiro: Biblioteca do Exército, 2005.

Recebido: 08/03/2016

Received: 03/08/2016

Aprovado: $30 / 05 / 2016$

Approved: 05/30/2016 